\title{
Passive immunization against highly pathogenic Avian Influenza Virus (AIV) strain H7N3 with antiserum generated from viral polypeptides protect poultry birds from lethal viral infection Mirza Imran Shahzad ${ }^{1}$, Khalid Naeem², Muhammad Mukhtar*1 and
} Azra Khanum ${ }^{1}$

Address: ${ }^{1}$ Department of Biochemistry, Pir Mehr Ali Shah Arid Agriculture University, Murree Rawalpindi-46300, Pakistan and ${ }^{2}$ National Reference Laboratory for Poultry Diseases (NRLPD), Animal Sciences Institute, National Agricultural Research Center (NARC), Islamabad, Pakistan

Email: Mirza Imran Shahzad - mirza.imran@uaar.edu.pk; Khalid Naeem - naeem22@comsats.net.pk; Muhammad Mukhtar* - muhammad.mukhtar@yahoo.com; Azra Khanum - azrakhanum@uaar.edu.pk

* Corresponding author

Published: 28 November 2008

Virology Journal 2008, 5:144 doi:10.1 186/1743-422X-5-144

This article is available from: http://www.virologyj.com/content/5/I/I44

(c) 2008 Shahzad et al; licensee BioMed Central Ltd.

This is an Open Access article distributed under the terms of the Creative Commons Attribution License (http://creativecommons.org/licenses/by/2.0), which permits unrestricted use, distribution, and reproduction in any medium, provided the original work is properly cited.
Received: 10 June 2008

Accepted: 28 November 2008

\begin{abstract}
Our studies were aimed at developing a vaccination strategy that could provide protection against highly pathogenic avian influenza virus (AIV), H7N3 or its variants outbreaks. A purified viral stock of highly pathogenic H7N3 isolate was lysed to isolate viral proteins by electrophresing on $12 \%$ sodium dodecyl sulfate polyacrylamide gel electrophoresis (SDS-PAGE), followed by their elution from gel through trituration in phosphate buffered saline (PBS). Overall, five isolated viral polypeptides/proteins upon characterization were used to prepare hyperimmune monovalent serum against respective polypeptides independently and a mixture of all five in poultry birds, and specificity confirmation of each antiserum through dot blot and Western blotting. Antiserum generated from various group birds was pooled and evaluated in 2-week old broiler chicken, for its protection against viral challenge. To evaluate in-vivo protection of each antiserum against viral challenges, six groups of 2-week old broiler chicken were injected with antiserum and a seventh control group received normal saline. Each group was exposed to purified highly pathogenic AIV H7N3 strain at a dose $10^{5}$ embryo lethal dose $\left(E L D_{50}\right)$. We observed that nucleoprotein (NP) antiserum significantly protected birds from viral infection induced morbidity, mortality and lowered viral shedding compared with antiserum from individual viral proteins or mixed polypeptides/proteins inclusive of NP component. The capability of individual viral polypeptide specific antisera to protect against viral challenges in decreasing order was nucleoprotein (NP) $>$ hemagglutinin $(\mathrm{HA})>$ neuraminidase $(\mathrm{NA})>$ viral proteins mix $>$ viral polymerase $(\mathrm{PM})>$ nonstructural proteins (NS). Our data provide proof of concept for potential utilization of passive immunization in protecting poultry industry during infection outbreaks. Furthermore conserved nature of avian NP makes it an ideal candidate to produce antiserum protective against viral infection.
\end{abstract}




\section{Background}

Avian influenza virus (AIV) besides reducing commercial production of poultry is also a causative agent for influenza among humans by cross-species infections [1]. The viral genome encodes 10 proteins and among these two surface proteins haemagglutinin and neuraminidase have main importance in viral classification [2]. AIV grouping is based on antigenic variations in haemagglutinin (H1 H16) and neuraminidase (N1 - N9) proteins and each strain of virus is named based on respective $\mathrm{H}$ and $\mathrm{N}$ antigenicity [3]. According to virulence pattern in poultry, the AIV is mainly classified into two major groups: highly pathogenic avian influenza (HPAI) and low pathogenic avian influenza (LPAI). The HPAI strains are highly virulent and associated with bird mortality approaching $100 \%$, whereas LPAI viruses manifest mild symptoms like decreased egg production and scruffy feathers. Throughout the world majority of avian influenza epidemics are due to HPAI viruses showing $\mathrm{H} 5$ and $\mathrm{H} 7$ antigenicity $[4,5]$. In Pakistan, low pathogenic H9N2 along-with high pathogenic H7N3 and H5N1 are the most predominant AIV strains and several outbreaks over the past decades are ascribed to these particular strains [6-8].

Avian influenza (AI) has emerged as a disease with significant potential to disrupt commercial poultry production, resulting in heavy losses to poultry farmers in several parts of the world. Due to fastidious viral genome, conventional antivirals against AIV are unable to control the infection and very few effective vaccines are available. Moreover, geographic strain variations have made it difficult to implement universal avian influenza vaccine strategy. As such, there has been an urgent need to develop broad spectrum antivirals against AIV or vaccines capable of coping with viral genomic changes. One of the most plausible options to control $\mathrm{AI}$ is development of regional immunization programs against the serotype involved in an outbreak. However, as the immunization has to be carried out prior to disease for establishing therapeutic levels of antibodies against the infection, in case of its sudden outbreak such control measures are not possible. Passive immunization has emerged as an effective therapeutic tool in the face of an outbreak; however its effectiveness in the case of AIV has not yet been investigated. During past decade, AIV, H7 serotype has caused high poultry birds mortality in different countries including Pakistan [6]. The whole virus killed AIV vaccines used against $\mathrm{H} 7$ has been found to be effective in reducing the clinical conditions of the birds upon subsequent field challenge [2]. However, practically it is always difficult to make use of any kind of killed vaccines during the outbreaks due to very short incubation period associated with highly pathogenic AI infection. Keeping this in view, the present study was designed to compare various viral proteins for their potentials as a vaccine candidate. According to our data nucleoprotein (NP) antiserum significantly protected birds from viral infection induced morbidity/mortality and lowered viral shedding compared with antiserum from other viral proteins like hemagglutinin (HA) neuraminidase (NA), viral polypeptides mix, non structural protein and viral polymerase enzyme. This proof of concept study provides initial data to rely on utilization of individual viral protein for passive immunization programs.

\section{Results}

Our initial work on SDS-PAGE analysis of H7N3 viral lysate showed five major viral proteins: high molecular weight polymerase (PM), hemagglutinin (HA), nucleoprotein (NP), neuraminidase (NA) and non-structural protein (NS) as shown in Figure 1. These polypetides were further concentrated and subjected to electrophoresis on SDS-PAGE. Five obvious bands of AIV viral polypetides were cut from the gel, triturated and diluted with $1.0 \mathrm{ml}$ of normal saline. This follows generation of polypeptide specific antibodies against each polypeptide and also a mixture of all was used to generate antisera. The specificity of each polypeptide antiserum was confirmed by DotELISA. Intriguingly, the viral peptides mix antisera detected H7N3 viral particles at 1:4 dilution (Figure 2).

All the birds used in this study were confirmed negative against AIV H7N3 antibodies by HI test. Passive immunization with individual polypeptide/protein specific antisera followed challenge with highly pathogenic AIV, H7N3. After 48 hours birds immunized with antisera and non-immunized control group were challenged with 0.2 $\mathrm{ml}$ of H7N3 viral strain A/Chicken/Pakistan/Murree/ NARC/69/04 (H7N3). Birds' morbidity, mortality and cloacal shedding were observed over a time period of twoweek. Four out of the six vaccinated group showed protec-

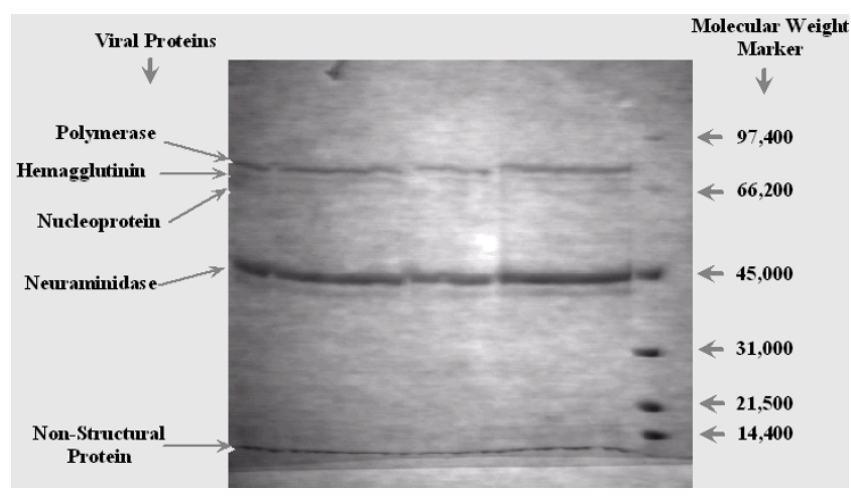

Figure I

SDS-PAGE analysis of avian influenza Virus strain

H7N3 proteins. Five major viral proteins are marked on gel corresponding to their molecular weight ascertained through protein molecular weight marker. 


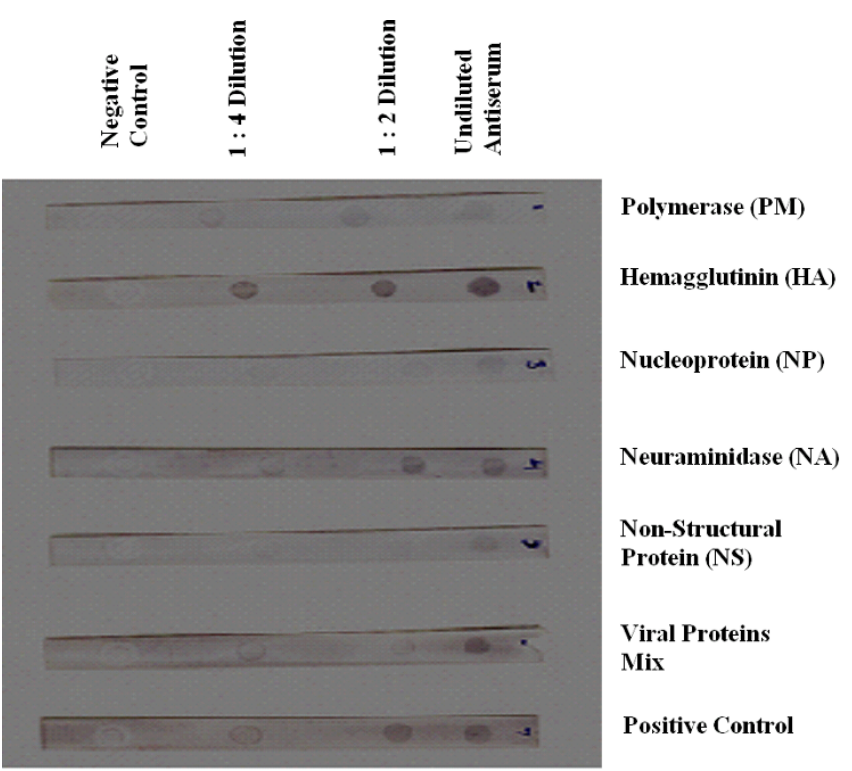

Figure 2

Dot-ELISA. confirms the antiserum specificity against respective polypetide.

tion from lethal viral challenge whereas negative control group showed highest level of mortality, morbidity and cloacal shedding. The level of protection in the four groups varied and nucleoprotein antiserum vaccinated group birds showed highest protection revealed by least mortality, and low viral shedding (60\%). The birds passively immunized with polymerase and non-structural protein antiserum showed no protection at all. Upon viral challenge, seven out of ten birds died in polymerase and non-structural protein antiserum vaccinated groups, whereas eight in non-vaccinated control group (Table 1). This trend continued and on day $4^{\text {th }}$ all the birds in PM, NS and control (normal saline group) were dead. Mortality was associated with extensive morbidity in polypeptides groups showing less protection. One of the groups was vaccinated with antiserum generated from a mixture of all five peptides (viral polypeptides mix group). It was intriguing to note that on day $4^{\text {th }}$ two birds died in this group without any further mortality thus showing $80 \%$ protection. No mortality (100\% protection) was observed in birds pre-vaccinated with hemagglutinin, nucleoprotein, and neuraminidase antisera. However, morbidity and viral shedding revealed $80-100 \%$ birds infected in HA vaccinated group, $20-60 \%$ in NP and $80-100 \%$ in NA groups (Table 1).

Morbidity describes disease condition and prevalence of various symptoms associated with viral infection in birds. In case of bird flu outbreak, the infected birds manifest quite distinctive symptoms like ruffled feathers, excessive thirst, areas of diffuse hemorrhage between the hocks and feet, edema surrounding the eyes, watery green diarrhea progressing to white and several others. Mortality in the control (non-vaccinated) and two of the viral peptides $(\mathrm{PM}, \mathrm{NS})$ antisera manifesting least protection $(0 \%)$ was associated with several disease symptoms an indicator for high morbidity $(100 \%)$. In comparing the data of all protective antisera groups, the level of morbidity was higher in viral polypeptides and neuraminidase groups (100\%) followed by hemagglutinin $(80 \%)$ on day $4^{\text {th }}$. The nucleoprotein antiserum immunized group showed the least morbidity (maximum 60\%) at day 4 along-with no mortality $(0 \%)$ and lowest level of cloacal shedding makes it a potential candidature for poultry vaccine against H7N3 especially through passive immunization route.

In vaccinated groups challenged with lethal AIV, NP groups showed least cloacal shedding of virus among all the groups. All other vaccinated and non-vaccinated control manifested cloacal shedding of virus. These data are quite interesting and will help us in designing future vaccine for AIV in poultry.

\section{Discussion}

Infections associated with AIV are threatening economy of several countries throughout the World. Particularly in South-East Asia viral infection has inflicted major losses to poor poultry farm holders as well as it poses a threat of cross-species infection among humans. AIV is a member of Type A group viruses and compared with its counterparts Type $B$ and $C$ has broad host range capable of causing infections in several birds and mammals. One of the major threats of AIV has been its capability to cross-species jumping i.e. from birds to humans [9].

According to a report from the International Federation for Animal Health (IFAH) vaccination strategies for controlling AIV infection in birds is one of the major viable options compared with other control measures [10]. Several vaccine strategies including production of vaccine from virus like particles are on horizon [11,12]. Killed vaccines have also been considered to control viral pandemic in flocks in-spite of its limitation in surveillance programs involving differentiation of infected from vaccinated animals (DIVA) test [2] particularly if killed vaccines are being used. For differentiating vaccinated birds from the naturally infected ones DIVA test strategy relies on detecting antibodies against $\mathrm{N}$-type only found in infected birds and not against serotype of vaccine strain, besides general monitoring strategy of unvaccinated sentinels.

Passive immunization with antiserum generated from viral polypeptides antigenic determinants has shown significant protection in mammals $[13,14]$ and also in birds [15]. We employed a passive immunization strategy by utilizing various proteins of AIV to ascertain which one of 


\begin{tabular}{|c|c|c|c|c|c|c|c|c|c|c|c|c|c|}
\hline \multirow{3}{*}{$\begin{array}{c}\text { Groups } \\
\\
1\end{array}$} & \multirow{3}{*}{$\begin{array}{c}\begin{array}{c}\text { Antisera against viral } \\
\text { protein(s) }\end{array} \\
\\
\text { Viral polymerase }\end{array}$} & \multicolumn{4}{|c|}{ Post-challenge mortality at different days } & \multicolumn{4}{|c|}{ Post-challenge morbidity at different days } & \multicolumn{4}{|c|}{ Post-challenge cloacal shedding at different days } \\
\hline & & 2 & 4 & 7 & 14 & 2 & 4 & 7 & 14 & 2 & 4 & 7 & 14 \\
\hline & & $7 / 10$ & $10 / 10$ & -- & -- & $3 / 10$ & -- & -- & -- & $3 / 10$ & -- & -- & -- \\
\hline 2 & Hemagglutinin & $0 / 10$ & $0 / 10$ & $0 / 10$ & $0 / 10$ & $4 / 10$ & $8 / 10$ & $8 / 10$ & $0 / 10$ & $10 / 10$ & $10 / 10$ & $8 / 10$ & $2 / 10$ \\
\hline 3 & Nucleoprotein & $0 / 10$ & $0 / 10$ & $0 / 10$ & $0 / 10$ & $2 / 10$ & $6 / 10$ & $5 / 10$ & $0 / 10$ & $6 / 10$ & $6 / 10$ & $5 / 10$ & $0 / 10$ \\
\hline 4 & Neuraminidase & $0 / 10$ & $0 / 10$ & $0 / 10$ & $0 / 10$ & $9 / 10$ & $10 / 10$ & $8 / 10$ & $0 / 10$ & $10 / 10$ & $10 / 10$ & $8 / 10$ & $3 / 10$ \\
\hline 5 & Non-structural protiens & $7 / 10$ & $10 / 10$ & -- & -- & $3 / 10$ & -- & -- & -- & $3 / 10$ & -- & -- & -- \\
\hline 6 & Viral polypeptides mixed & $0 / 10$ & $2 / 10$ & $0 / 8$ & $0 / 8$ & $10 / 10$ & $8 / 8$ & $7 / 8$ & $0 / 8$ & $10 / 10$ & $8 / 8$ & $7 / 8$ & $2 / 8$ \\
\hline 7 & Normal saline & $8 / 10$ & $10 / 10$ & -- & -- & $2 / 10$ & -- & -- & -- & $2 / 10$ & -- & -- & -- \\
\hline
\end{tabular}


these could be comparatively a better candidate for the generation of antisera to be used for passive immunization. The viral polypeptides used in this study were from a highly pathogenic avian influenza virus serotype H7N3 that has been previously reported in Pakistan and several other parts of the world $[6,7,16]$. Our proof of concept studies reveal that it is possible to develop passive immunization strategies against AIV subtype by using viral proteins and among the five viral proteins (hemagglutinin, neuraminidase, nucleoproteins, non-structural protein, polymerase, and a mixture of all these) nucleoprotein generated antiserum provided better protection in birds upon challenge with highly pathogenic avian influenza virus.

Four out of six vaccines have given protection in decreasing order $\mathrm{NP}>\mathrm{HA}>\mathrm{NA}>$ viral polypeptides mix. In case of HA, NA and viral polypeptides mix, the level of infection increased from day 0 to day 4 and then it decreased till the end of experiment i.e. day 14. NP antiserum besides providing $100 \%$ protection also boosted chick's immunity manifested as sustained resistance against infection (low level of morbidity and viral shedding) as compared to other vaccine groups. These data suggest that passively transfused anti-NP antibodies have a better antiviral neutralizing effect and overall protection from AIV. Overall, a better protection provided during days $7-14$ is due to immune regulation.

Considering the situation of developing nations like Pakistan passive immunization strategy will be economical and targeted. Avian Influenza is capable of changing antigenic determinants that leads to inefficacy of vaccines. A locally produced economical vaccine will provide effective and long lasting solution to this pandemic especially the non-variant parts (nucleoproteins) that hold the promising future of AIV vaccines.

\section{Materials and methods}

Prior to beginning this study the protocol was reviewed and approved by the animal biosafety committee of the Pir Mehr Ali Shah Arid Agriculture University Rawalpindi, and all the viral challenges and preparations were conducted at the biosecure facilities of the National Reference Laboratory for Poultry Diseases (NRLPD) at the Animal Sciences Institute, National Agriculture Research Center (NARC), Islamabad, Pakistan.

\section{Viral stocks}

A previously isolated highly pathogenic AIV serotype H7N3 A/Chicken/Pakistan/Murree/NARC/69/04 (H7N3) [17] was obtained from the repository of the NRLPD at Animal Sciences Institute, National Agricultural Research Center (NARC), Islamabad. The viral stock was reactivated in the allantoic cavity of embryonated hen's eggs as described previously [18]. Agar gel precipitation test was used to confirm the presence of AIV in the allantoic fluid [19] and HA test was performed to calculate the viral titer, whereas embryo lethal dose $50\left(\mathrm{ELD}_{50}\right)$ titer of the fresh viral stock was determined by classical Reed and Muench [20] methodology. In brief, this involves 10 fold serial dilutions of stock virus in normal saline $\left(10^{1}\right.$ to $\left.10^{12}\right)$ followed by injecting $0.2 \mathrm{ml}$ of each dilution into the chorioallantoic region of embryonated eggs. The mortality of eggs is recorded and $\mathrm{ELD}_{50}$ calculated as described previously[20].

\section{Preparation of viral polypeptides and production of monovalent hyperimmune antisera}

Purified fresh stock of H7N3 AIV was lysed with 4\% Triton $\mathrm{X}-100$ using $0.01 \mathrm{M}$ Tris buffer ( $\mathrm{pH} 7.2$ ) in the presence of $1 \mathrm{mM} \mathrm{KCl}$. Viral lysate was stirred for 45 minutes at room temperature followed by centrifugation at $10,000 \times \mathrm{g}$ to get the supernatant containing HA, NA and matrix (M) proteins. The pellet containing NP protein was washed with phosphate buffer saline (PBS), by re-centrifuging at $10,000 \times \mathrm{g}$ for 1 hour at $4^{\circ} \mathrm{C}$. To remove viral DNA/viral particles the supernatant was centrifuged at $200,000 \times \mathrm{g}$ by using Beckman ultracentrifuge L8-80 on $50 \mathrm{Ti}$ rotor (Beckman, USA) for 1 hour to remove the viral DNA and viral particles. The supernatant was collected and dialyzed against $0.01 \mathrm{M}$ PBS for 48 hours. It was again centrifuged at $10,000 \times \mathrm{g}$ for 10 minutes to separate $\mathrm{M}$ protein out of these preparations and the resulting pellet was suspended in PBS. The supernatant containing HA, NA, polymerase (PM) and non-structural (NS) proteins was collected by centrifuging three times repeatedly at $10,000 \times \mathrm{g}$ for 10 minutes at $4{ }^{\circ} \mathrm{C}$. The supernatants were dialyzed and the resultant collections were analyzed on $12 \%$ polyacrylamide gel. Five bands of AIV proteins separated on the gel were cut, triturated and diluted with $1 \mathrm{ml}$ of normal saline solution (NSS). The material was centrifuged at $1000 \times \mathrm{g}$ for $10 \mathrm{~min}$ and supernatant was quantified by Lowry's method [21]. Each polypeptide was emulsified with complete Freund's adjuvant and injected @ $4 \mu \mathrm{g} / \mathrm{bird} /$ injection via subcutaneous route in six groups of four birds each (fourth bird was a negative control), twice at two weeks interval, respectively.

\section{Dot-ELISA}

Dot-ELISA was standardized and performed to check the specificity of each polypeptide specific antisera against AI H7N3 virus. Antigen dots were used in different dilutions ranging from Neat virus to 1:4 dilutions with NSS along with a dot containing BSA as a negative control.

\section{Passive immunization with polypeptides specific antisera} Broiler chicks tested negative for AIV were divided equally into seven group of ten each. These birds were reared under strict isolation and high security conditions in 
chicken isolators. At the age of two weeks, birds were passively immunized with $4 \mathrm{ml}$ each of the polypeptide specific antisera. Birds were challenged while rearing in chicken isolators at 24 hours post inoculation (PI) with live virus of AI serotype $\mathrm{H} 7 \mathrm{~N} 3$ at a dose $10^{5} \mathrm{ELD}_{50}$. The birds were examined for clinical signs, mortality and cloacal shedding, up to 14 days post-challenge (PC).

\section{Acknowledgements}

This work was supported by the Agricultural Linkage Program (ALP) grant from the Pakistan Agricultural Research Council to KN, Department of Biochemistry, PMAS Arid Agricultural University Rawalpindi research funds to AK and Foreign Faculty Hiring Program of the Higher Education Commission Pakistan support to MM.

\section{References}

I. Alexander DJ: Avian influenza viruses and human health. Developments in biologicals 2006, I 24:77-84.

2. Suarez DL: Overview of avian influenza DIVA test strategies. Biologicals 2005, 33:221-226.

3. World Health Organization Expert Committee report on "A revision of the system of nomenclature for influenza viruses: a WHO Memorandum". Bull WHO 1980, 58:585-59I.

4. Tweed SA, Skowronski DM, David ST, Larder A, Petric M, Lees W, Li Y, Katz J, Krajden M, Tellier R, Halpert C, Hirst M, Astell C, Lawrence $D$, Mak A: Human illness from avian influenza H7N3, British Columbia. Emerging infectious diseases 2004, 10:2196-2199.

5. Tran TH, Nguyen TL, Nguyen TD, Luong TS, Pham PM, Nguyen VC, Pham TS, Vo CD, Le TQ, Ngo TT, Dao BK, Le PP, Nguyen TT, Hoang TL, Cao VT, Le TG, Nguyen DT, Le HN, Nguyen KT, Le HS, Le VT, Christiane D, Tran TT, Menno de J, Schultsz C, Cheng P, Lim W, Horby $\mathrm{P}$, Farrar J: Avian influenza A (H5NI) in 10 patients in Vietnam. The New England journal of medicine 2004, 350:I I 79- I I 88.

6. Naeem K, Siddique N: Use of strategic vaccination for the control of avian influenza in Pakistan. Developments in biologicals 2006, I 24:145-150.

7. Naeem K, Siddique N, Ayaz M, Jalalee MA: Avian influenza in Pakistan: outbreaks of low- and high-pathogenicity avian influenza in Pakistan during 2003-2006. Avian diseases 2007 5I:189-193.

8. Naeem K, Ullah A, Manvell RJ, Alexander DJ: Avian influenza A subtype H9N2 in poultry in Pakistan. The Veterinary record 1999 I 45:560.

9. Ernst WA, Kim HJ, Tumpey TM, Jansen AD, Tai W, Cramer DV Adler-Moore JP, Fujii G: Protection against $\mathrm{HI}, \mathrm{H5}, \mathrm{H} 6$ and $\mathrm{H9}$ influenza $A$ infection with liposomal matrix 2 epitope vaccines. Vaccine 2006, 24:5158-5168.

10. IFAH: IFAH background paper on Avian Influenza Vaccination. 2006 [http://www.ifahsec.org].

II. Quan FS, Huang C, Compans RW, Kang SM: Virus-like particle vaccine induces protective immunity against homologous and heterologous strains of influenza virus. Journal of virology 2007, 8I:35|4-3524.

12. Swayne DE, Suarez DL: Current developments in avian influenza vaccines, including safety of vaccinated birds as food. Developments in biologicals 2007, I 30: 123-133.

13. Foo DG, Alonso S, Chow VT, Poh CL: Passive protection against lethal enterovirus $7 I$ infection in newborn mice by neutralizing antibodies elicited by a synthetic peptide. Microbes and infection 2007, 9:1299-1306.

14. Ledizet M, Kar K, Foellmer HG, Bonafe N, Anthony KG, Gould LH, Bushmich SL, Fikrig E, Koski RA: Antibodies targeting linear determinants of the envelope protein protect mice against West Nile virus. The Journal of infectious diseases 2007 , 196: $174 \mid-1748$

15. Chambers TM, Kawaoka Y, Webster RG: Protection of chickens from lethal influenza infection by vaccinia-expressed hemagglutinin. Virology 1988, 167:4|4-42|

16. Alexander DJ: Summary of avian influenza activity in Europe, Asia, Africa, and Australasia, 2002-2006. Avian diseases 2007, 5I:16I-166.
17. Sattar S, Naeem K, Ahmed Z, Malik SA: Influence of virus strain on the efficacy of vaccine against avian influenza virus subtype H7N3. International Journal of poultry science 2007, 6:989-993.

18. Lu J, Guo Z, Pan X, Wang G, Zhang D, Li Y, Tan B, Ouyang L, Yu X: Passive immunotherapy for influenza A H5N I virus infection with equine hyperimmune globulin $\mathbf{F}\left(\mathrm{ab}^{\prime}\right) \mathbf{2}$ in mice. Respiratory research 2006, 7:43.

19. Sakai K, Yada K, Sakabe G, Tani O, Miyaji K, Nakamura M, Takehara $K$ : Serological and virological studies of Newcastle disease and avian influenza in slaughter-age ostriches (Struthio camelus) in Japan. The Journal of veterinary medical science/the Japanese Society of Veterinary Science 2006, 68:491-494.

20. Reed LJ, Muench H: A simple method of estimating fifty percent end points. American journal of hygiene 1938, 27:493-498.

21. Lowry OH, Rosbrough NJ, Farr AL, Randall RJ: Protein measurement with the Folin phenol reagent. J Biol Chem I95I, I 93(I):265-275.

Publish with Bio Med Central and every scientist can read your work free of charge

"BioMed Central will be the most significant development for disseminating the results of biomedical research in our lifetime. "

Sir Paul Nurse, Cancer Research UK

Your research papers will be:

- available free of charge to the entire biomedical community

- peer reviewed and published immediately upon acceptance

- cited in PubMed and archived on PubMed Central

- yours - you keep the copyright 